УДК 351.777:502/.504

DOI https://doi.org/10.32837/pyuv.v0i2(27).206

М. М. Сливка

асистент кафедри адліністративного та інфорлаційного права Навчально-наукового інституту права, психологї та інноваційної освіти Національного університету «Львівська політехніка»

\title{
ПОНЯТТЯ, ПРИНЦИПИ ТА РОЛЬ ВЗАЕМОДІЇ СУБ'СКТІВ ОХОРОНИ НАВКОЛИШНЬОГО ПРИРОДНОГО СЕРЕДОВИЩА
}

Покращення стану навколишнього природного середовища можна досягнути за умови вдосконалення адміністративного та екологічного законодавства на державному рівні, розробки та прийняття дієвих програм на рівні територіальних громад, налагодження системи моніторингу, а також забезпечення системної взаємодії суб'єктів у сфері охорони довкілля.

Вивчення взаємодії суб'єктів охорони навколишнього природного середовища знаходить своє відображення у працях таких науковців, як В.А. Зуєв, І.Д. Казанчук, Н.І. Золотарьова, О.С. Мірошниченко, В.Ю. Ксендзюк, В.М. Тюн, Ю.С. Назар, та інших.

Метою статті є дослідження поняття, принципів, а також встановлення ролі взаємодії суб'єктів охорони навколишнього природного середовища.

Сучасна система забезпечення охорони навколишнього природного середовища має базуватися на взаємодії органів державної влади, органів місцевого самоврядування, а також громадських формувань, що вимагає покращення правовоі бази і вивчення міжнародного досвіду щодо вирішення екологічних проблем.

Аналіз наукової літератури свідчить про відсутність єдиного підходу вчених до визначення сутності поняття «взаємодія».

У теорії управління взаємодію розглядають у двох аспектах: як категорію, яка є визначальною для всього процесу управління, та як діяльність кількох суб'єктів із спільною метою. Прихильником цієї теорії є В.К. Колпаков, який вважає, що "управлінська система - це єдине ціле, що існує і розвивається завдяки взаємодії його компонентів» $[1$, с. 10$]$.

O.М. Ярмак акцентує увагу на тому, що взаємодія виникає там і тоді, де взаємозв'язок між суб'єктами зумовлений спільною метою. Крім того, взаємодія полягає не лише у безперервному впливі один на одного, а також у використанні взаємодіючими сторонами можливостей один одного для досягнення власних цілей. Якщо за формою взаємодія подається як взаємозв'язок між суб'єктами, то за змістом вона є засобом обміну будь-якою інформацією. Отже, є усі підстави вважати взаємодію фундаментальною умовою процесу здійснення державного управління [2, с. 8].
Ю.С. Назар вважає, що взаємодію у вузькому розумінні (взаємодію суб'єктів управління) можна визначити як управлінський процес, який полягає у діяльності кількох (не менше двох) суб'єктів, які впливають один на одного та на об'єкт засобами і методами, що властиві кожному учасникові для досягнення спільної мети [3, с. 17].

Як зазначає О.М. Васильєва, взаємодія полягає у певній організаційній діяльності як шлях до мети на основі узгодженості дій суб’єктів. Зокрема, на організаційному етапі взаємодії здійснюється:

1) нормативно-правове забезпечення взаємодії;

2) реалізація нормативно-правового забезпечення;

3) безпосереднє планування заходів із взаємодії $[4$, с. 99, 102].

В.Д. Пчолкін розглядає взаємодію як засновану на спільності цілей і завдань, погоджену за часом, місцем і змістом, визначену законодавством діяльність компетентних суб'єктів щодо раціонального застосування наявних сил, засобів і методів для забезпечення охорони громадського порядку та громадської безпеки [5, с. 97].

Взаємодії притаманні певні ознаки, які дають можливість з'ясувати її суть та відмежувати від схожих явищ:

1) взаємодія - це діяльність;

2) наявність декількох (не менше двох) суб'єктів взаємодії;

3) узгодженість заходів щодо цілі, місця, часу, методів;

4) спрямованість функціонування суб'єктів взаємодії;

5) наявність нормативної (правової) бази взаємодії;

6) становище суб’єктів у ієрархії системи;

7) зміст завдань, які вирішуються суб’єктами взаємодії;

8) сумісна діяльність [6, с. 298-299].

До основних ознак взаємодії в сфері охорони навколишнього середовища можемо віднести такі: взаємодія як форма природоохоронної діяльності; наявність декількох суб'єктів; спільна мета; екологічна спрямованість діяльності; комплексний підхід до вирішення завдань; системність і спрямованість дій; узгодженість нормативно-правової бази; інформованість суб'єктів взаємодії; своєчас- 
ність та оперативність у прийнятті узгоджених рішень; об’єднання сил та засобів для досягнення позитивного результату.

На нашу думку, взаємодія суб'єктів охорони навколишнього природного середовища - це врегульована нормами адміністративного права діяльність суб'єктів охорони навколишнього природного середовища, заснована на засадах взаємодопомоги та партнерства, зумовлена спільною метою і завданням та спрямована на забезпечення екологічної безпеки громадян і недопущення шкідливих впливів на довкілля.

Взаємодія суб'єктів охорони навколишнього природного середовища як «управлінський процес» повинна базуватись на певних принципах, які сприятимуть підвищенню ефективності виконання покладених на них завдань.

О.Ф. Скакун визначає принципи права як об’єктивно властиві праву відправні начала, незаперечні вимоги (позитивні зобов'язання), які ставляться до учасників суспільних відносин із метою гармонічного поєднання індивідуальних, групових і громадських інтересів [7, с. 221].

На думку 0.0. Уварової, принципи права можна визначити як систему вимог до належної і можливої поведінки людей, які відображають визнані у суспільстві цінності і утворюють спрямовану на регулювання суспільних відносин ієрархічну єдність [8, с. 55].

Під принципами взаємодії суб'єктів охорони навколишнього природного середовища пропонуємо розуміти закріплені в нормах права керівні ідеї, начала, які визначають та спрямовують діяльність суб’єктів цієї взаємодії, задля належного виконання ними поставлених завдань.

Вчені мають різні погляди щодо класифікації принципів взаємодії суб'єктів. Одні пропонують недиференційований перелік тих принципів, які найбільш чітко характеризують і розкривають предмет дослідження. Інші поділяють ці принципи на дві основні категорії: загальні та спеціальні.

Так, до прикладу, ще В.М. Плішкін зазначав, що взаємодія буде найбільш ефективною, якщо вона грунтуватиметься на системі таких принципів: науковості; законності; плановості; безперервності; «головної ланки»; «резерву»; маневреності; оптимального використання можливостей взаємодіючих елементів; пропорційної відповідальності за наслідки взаємодії [9, с. 506].

На противагу вказаному вище підходу В.М. Плішкіна, Д.Г. Заброда під час дослідження питання принципів взаємодії суб'єктів боротьби з корупцією пропонує усі принципи поділяти на загальні та спеціальні.

Так, до загальних Д.Г. Заброда пропонує віднести: 1) законність; 2) науковість; 3) плановість; 4) гласність; 5) безперервність; 6) системність; 7) комплексність; 8) наступальність. До спеціальних принципів Д.Г. Заброда відносить: 1) спільності інтересів; 2) «головної ланки»; 3) «маневреності»; 4) паритетності (рівності); 5) спеціалізованості; 6) пропорційної відповідальності; 7) непересічення компетенції 8) комплексного використання сил та засобів взаємодіючих сторін [10, с. 10].

Вважаємо, що перелік загальних принципів $€$ досить вичерпним і розширення чи доповнення не потребує. Поряд з цим, на нашу думку, раціональним видається доповнення групи спеціальних принципів такими:

1) протидії екологічним правопорушенням;

2) забезпечення екологічної безпеки громадян;

3) партнерства та взаємодопомоги;

4) швидкого реагування та притягнення винних до відповідальності;

5) альтернативності вибору покарання;

6) взаємоконтролю;

7) невідворотності покарання за неналежне виконання покладених обов'язків.

Принцип протидії екологічним правопорушенням передбачає попередження, виявлення або ж припинення екологічних правопорушень, які створюють потенційну небезпеку для навколишнього природного середовища.

Принцип забезпечення екологічної безпеки громадян передбачає таку взаємодію суб'єктів охорони навколишнього природного середовища, яка сприяє стану захищеності життя і здоров'я людини, навколишнього природного середовища від потенційних екологічних загроз та негативних впливів природного чи техногенного характеру.

Принцип партнерства та взаємодопомоги передбачає об'єднання потенціалу, сил та засобів суб'єктів взаємодії у сфері охорони навколишнього природного середовища задля досягнення спільного позитивного результату під час вирішення екологічних проблем.

Принцип швидкого реагування та притягнення винних до відповідальності має своїм покликанням швидке виявлення правопорушень у сфері охорони навколишнього природного середовища та максимально швидке й ефективне притягнення винних осіб до відповідальності, передбаченої законом.

Принцип альтернативності вибору покарання полягає у можливості уповноважених державних органів та/або посадових осіб на власний розсуд вибирати одну з передбачених законом санкцій 3 метою притягнення до відповідальності осіб, винних у порушенні екологічного законодавства.

Принцип взаємоконтролю означає, що всі суб'єкти взаємодії у сфері охорони навколишнього природного середовища здійснюють контроль один за одним з метою найбільш ефективного виконання поставлених перед ними завдань, недопущення зловживання правами чи недбалого виконання покладених обов'язків. 
Принцип невідворотності покарання за неналежне виконання покладених обов'язків передбачає застосування санкцій до уповноважених посадових осіб суб'єктів взаємодії у сфері охорони навколишнього природного середовища у разі неналежного виконання ними своїх обов'язків. Актуальність цього принципу пояснюється збільшенням випадків бездіяльності суб'єктів взаємодії у сфері охорони навколишнього природного середовища.

Дотримання вищезазначених принципів сприятиме покращенню взаємодії суб'єктів охорони навколишнього природного середовища.

Взаємодія суб'єктів охорони навколишнього природного середовища відіграє важливу роль, оскільки:

- дозволяє своєчасно виявляти екологічні правопорушення та вживати відповідні заходи впливу до порушників природоохоронних норм;

- забезпечує ефективне та оперативне вирішення нагальних проблем у сфері охорони довкілля; - об'єднує потенціал учасників взаємодії та стимулює до пошуку новаторських методів боротьби з екологічними правопорушеннями;

- сприяє зменшенню кількості вчинення екологічних правопорушень;

- посилює роль кожного суб'єкта взаємодії у вирішенні питань, що стосуються охорони навколишнього природного середовища;

- дозволяє досягти бажаного результату у вирішенні екологічних проблем;

- сприяє покращенню стану навколишнього природного середовища, а відтак - забезпеченню реалізації екологічних прав громадян.

Потреба в захисті навколишнього природного середовища від шкідливого антропогенного впливу з кожним роком зростає, а це своєю чергою посилює роль взаємодії суб'єктів охорони довкілля.

Налагодження ефективної взаємодії суб'єктів охорони навколишнього природного середовища $\epsilon$ важливим елементом процесу демократизації суспільства, охорони довкілля та забезпечення екологічної безпеки громадян.

\section{Jimepamypa}

1. Колпаков В.К. Адміністративне право України : підручник. Київ : Юрінком Інтер, 1999. 736 с.

2. Ярмак О.М. Адміністративно-правові засади взаємодії органів державної влади України у правоохоронній сфері : автореф. дис. ... канд. юрид. наук : 12.00.07. Київ, 2009. 18 с.

3. Назар Ю.С. Взаємодія органів внутрішніх справ із місцевими органами виконавчої влади та органами місцевого самоврядування у профілактиці адміністративних правопорушень : монографія. Львів : Львівський державний університет внутрішніх справ, 2012. $160 \mathrm{c}$.

4. Васильева О.М. Некоторые теоретические вопросы взаимодействия органов внутренних дел с добро- вольными народными дружинами. Вопросы взаимодействия с общественностью. Москва, 1977. С. 98-104.

5. Пчолкін В.Д. Поняття, сутність та завдання взаємодії оперативних підрозділів органів внутрішніх справ. Проблеми взаємодії територіальних і транспортних органів внутрішніх справ у попередженні та розкритті злочинів : наук.-практ. конф. 23 травня 2003 р. : тези доповіді. Львів, 2004. С. 93-104.

6. Організація управління персоналом в органах внутрішніх справ : монографія / В.Д. Сущенко, А.М. Смирнов, О.І. Коваленко, А.А. Смирнов. Київ : Національна академія внутрішніх справ України, 1999. $352 \mathrm{c}$.

7. Скакун О.Ф. Теорія держави і права : підручник / пер. з рос. Харків, 2001. 656 с.

8. Уварова 0.О. Принципи права у правозастосуванні: загальнотеоретична характеристика : монографія. Харків : Друкарня «МАДРИД», 2012. 196 с.

9. Теорія управління органами внутрішніх справ : підручник / за ред. канд. юрид. наук Ю.Ф. Кравченка. Київ : Націон. акад. внутр. справ України, 1999. 702 с.

10. Заброда Д.Г. Взаємодія суб’єктів боротьби з корупцією : автореф. дис. ... канд. юрид. наук : 12.00.07. Київ, 2005. 20 с.

\section{Анотація}

Сливка М. М. Поняття, принципи та роль взаємодії суб'єктів охорони навколишнього природного середовища. - Стаття.

Статтю присвячено дослідженню поняття та визначенню ознак взаємодії суб'єктів охорони навколишнього природного середовища.

Сформульовано визначення поняття «взаємодія суб'єктів охорони навколишнього природного середовища» - це врегульована нормами адміністративного права діяльність суб'єктів охорони навколишнього природного середовища, заснована на засадах взаємодопомоги та партнерства, зумовлена спільною метою і завданням та спрямована на забезпечення екологічної безпеки громадян і недопущення шкідливих впливів на довкілля.

Визначено принципи взаємодії суб'єктів охорони навколишнього природного середовища як закріплені в нормах права керівні ідеї, начала, які визначають та спрямовують діяльність суб'єктів цієї взаємодії задля належного виконання ними поставлених завдань.

Виокремлено пріоритетні принципи взаємодії суб'єктів охорони навколишнього природного середовища: протидії екологічним правопорушенням, забезпечення екологічної безпеки громадян, партнерства та взаємодопомоги, швидкого реагування та притягнення винних до відповідальності, альтернативності вибору покарання, взаємоконтролю, невідворотності покарання за неналежне виконання покладених обов'язків.

Встановлено, що взаємодія суб'єктів охорони навколишнього природного середовища відіграє важливу роль, оскільки: 1) дозволяє своєчасно виявляти екологічні правопорушення та вживати відповідні заходи впливу до порушників природоохоронних норм; 2) забезпечує ефективне та оперативне вирішення нагальних проблем у сфері охорони довкілля; 3) об'єднує потенціал учасників взаємодії та стимулює до пошуку новаторських методів боротьби з екологічними правопорушеннями; 4) сприяє зменшенню кількості вчинення екологічних правопорушень тощо.

Ключові слова: поняття, принципи, взаємодія суб'єктів, охорона, навколишнє природне середовище. 


\section{Summary}

Slyvka M. M. Concepts, principles and role of interaction of subjects of environmental protection. - Article.

The article is devoted to the research of the concept and definition of signs of interaction of the subjects of environmental protection.

It is formulated the definition of the concept of "interaction of environmental protection entities" - the activity of environmental protection bodies regulated by norms is based on the principles of mutual assistance and partnership, determined by the common goal and objectives, and aimed at ensuring environmental safety of citizens and prevention harmful effects on the environment.

The principles of interaction of environmental protection subjects are specified like determined in the norms of law main ideas, beginnings that identify and direct the activities of the subjects of this interaction for the proper fulfillment of their tasks.
The priority principles of interaction of environmental protection subjects are specified: counteraction to environmental violations, provision of ecological safety of citizens, partnership and mutual assistance, rapid response and bringing the perpetrators to justice, alternative to the choice of punishment, control, inevitability of punishment for improper performance of assigned duties.

It is identified that the interaction of environmental protection subjects plays an important role, since: 1 ) it allows to detect "in time" environmental violations and take the appropriate measures of influence against violators of environmental norms; 2) ensure effective and prompt solution of urgent problems in the field of environmental protection; 3) unify the potential of the participants of the interaction and stimulates the search for innovative methods for combating against environmental offenses; 4) help to reduce the number of environmental offenses etc.

Key words: concepts, principles, interaction of subjects, protection, environment. 